\title{
Childhood Ovarian Dysgerminoma
}

National Cancer Institute

\section{Source}

National Cancer Institute. Childhood Ovarian Dysgerminoma. NCI Thesaurus. Code C6550.

A dysgerminoma that arises from the ovary and occurs in children. 